\title{
Elaboration et validation de tests de jugement situationnel comme outil de sélection professionnelle : guide méthodologique
}

\section{Development and validation of situational judgment tests as a tool for personnel selection: a methodological guide}

\author{
Benoit Lothe, Françoise Bertrand et Isabelle Hansez \\ Unité de Valorisation des Ressources Humaines, Université de Liège, 5, blv du Rectorat \\ (Bât.32), 4000 Liège, Belgique, \\ Courriels : Benoit.Lothe@ulg.ac.be ; Francoise.Bertrand@ulg.ac.be ; \\ ihansez@ulg.ac.be
}

\begin{abstract}
Résumé
Les perspectives actuelles en sélection professionnelle reconnaissent l'importance de créer des épreuves basées sur des mises en situation proches du contexte de travail. Les tests de jugement situationnel (TJS) constituent ainsi une méthode de plus en plus utilisée en Europe. Cette méthode a démontré différents avantages en termes de validité, d'acceptabilité auprès des candidats et d'économie sur les ressources nécessaires à sa mise en œuvre. Ce manuscrit propose une démarche structurée et accessible pour la création de ce type d'épreuve. Chaque étape est illustrée par des exemples et les aspects de validation psychométrique sont discutés.
\end{abstract}

\section{Summary}

Current views in personnel selection recognize the necessity for situational judgements tests (SJT) which are closed to the real work context of companies. The SJTs have also become a popular selection tool across Europe. SJTs are attractive because they show good validity, positive applicants reactions and can be cost effective to test large group of applicants at once. The aim of this paper is to describe a structured methodology for the elaboration of such test. Each stage is illustrated by examples and psychometrics validation issues are discussed.

Mots-clés: tests de jugement situationnel, élaboration d'épreuve, validation d'items.

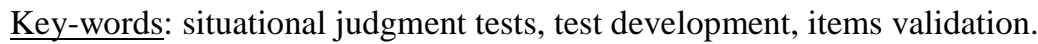

